\title{
Silvan Niedermeier
}

\section{Torture and "Modern Civilization": The NAACP's Fight against Forced Confessions in the American South (1935-1945)}

In April 1935, the National Association for the Advancement of Colored People (NAACP) published a report on the case of Henry Shields, Arthur Ellington, and Ed Brown. One year earlier, the three African American farm workers had been convicted and sentenced to death by a Mississippi court for the murder of a white tenant farmer. The article, published in the NAACP magazine The Crisis, featured a photograph on the front page. It showed Shields, Ellington, and Brown sitting next to each other on a bench in front of a white wall wearing prison suits while they had their eyes and faces turned towards the camera. Arthur Ellington, in the middle, was held upright by his two fellow inmates (see figure 1$)^{1}$.

In the accompanying report the editors provided background information on the scene:

Note that Ellington, in the center, is being held up by his two companions. That is because he is nearly dead from the torture he received when a confession was forced out of him. He was beaten and hanged a little at a time to make him confess. As a result his neck is damaged and he is injured so severely otherwise that he cannot sit up alone ${ }^{2}$.

By visualizing the results of the torture inflicted on Arthur Ellington during his interrogation, the editors apparently intended to highlight the dramatic implications of the case. As the readers were told, Ed Brown and Henry Shields too had been beaten "brutally" during the police interrogations in order to make them confess to the murder despite their claims of innocence. Closing the report, the editors appealed to NAACP members to give financial support to the organization in bringing the case to the U.S. Supreme Court:

Funds are badly needed by the national office for this and other legal cases pending. Practically all funds for this case must be raised outside of Mississippi. Immediate action is needed if these three farm workers are to be given a chance for live ${ }^{3}$.

1 The author wishes to thank the Crisis Publishing Co., Inc., the publisher of the magazine of the National Association for the Advancement of Colored People, for the use of images and material first published in the April 1935 and March 1941 issues of Crisis Magazine.

2 Escapes Noose; Near Death From Torture (see Cover), in: The Crisis (April 1935) 119.

3 Ibid. 
The case of Brown, Ellington, and Shields was the first in which the NAACP decided to launch a legal attack against the practice of police torture within the southern criminal justice system. In the following decade, the NAACP would become active in dozens of cases dealing with African American defendants who claimed to have been tortured into confessions by southern police officers and convicted based on "forced confessions"4. While southern lynchings had received national and even international attention since the late nineteenth century, the widespread use of police torture against African Americans within southern criminal justice institutions remained largely unnoticed by the American public until the mid-1930s, when the NAACP started to make visible the practice and attack it as a form of racial discrimination. This chapter examines the NAACP's campaign against forced confessions that reached its high point from 1935 to 1945.

As I will show, the NAACP employed different rhetorical strategies to emphasize the inhumanity and brutality of southern criminal justice institutions and to call for public support for the NAACP's fight against southern torture practices. In pursuit of its campaign against southern torture, the NAACP insisted that all forms of racial violence - whether carried out by lynch mobs outside the law or police supposedly operating within it - threatened the country's self-perceptions as a modern society. In doing so, the NAACP campaign against forced confession increased national attention to southern racial violence and secured public and financial support for the movement's legal activities.

First, I will sketch the institutional and legal background of the NAACP's involvement in southern forced confession cases. The NAACP's activities in this field were part of a broader legal campaign that was supported by several U.S. Supreme Court decisions during the 1920s and 1930s. In response to these decisions and the growing demand for legal assistance in criminal cases, the NAACP's legal department intensified its efforts on behalf of African American defendants convicted on the basis of tainted or false evidence obtained through police abuse.

Next, I will analyze how the NAACP framed and interpreted cases of southern police torture. Before 1940, the notion of "civilization" was central to the NAACP's campaign against southern police torture. As NAACP activists claimed, southern torture incidents challenged the American self-image as a modern, progressive, and civilized nation. The NAACP thus argued that the legal fight against forced confessions had a reformative effect upon American criminal justice institutions. As I will point out in the concluding part of the paper, these notions were modified during the early 1940s. With the outbreak of the Second World War, the NAACP began to use southern torture cases to point to the contradictions between racial violence in the American South and the fight for democracy abroad ${ }^{5}$.

4 While the NAACP legal department invented the term "forced confession case" to label this type of case, criminal justice literature uses the term "coerced confession case". Geneva Brown, Coerced Confessions / Police Interrogations, in: Encyclopedia of American Civil Liberties 1, ed. by Paul Finkelman (New York 2006) 315-321 [hereafter Brown, Coerced Confessions].

5 On the NAACP's forced confession campaign see also my dissertation on the history of 
Figure 1: Cover of the NAACP's monthly magazine The Crisis, April 1935.

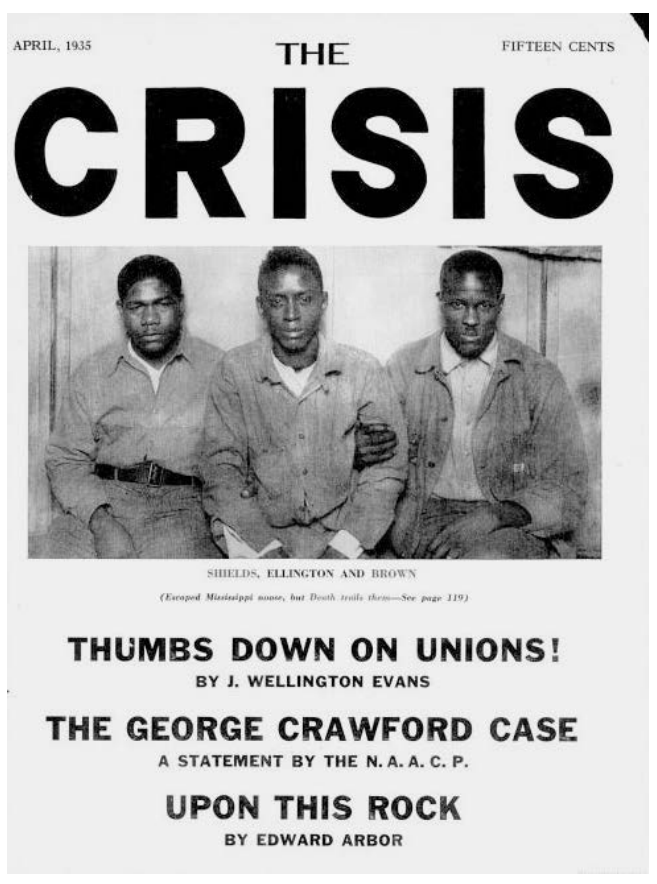

\section{“To secure equal justice in the courts": The NAACP's Legal Fight against "Forced Confessions"}

Starting in the mid-1930s, the NAACP's activities against forced confessions brought a certain form of violence into public view that was present throughout the United States during the first half of the 20th century. In 1931, a report of the Wickersham Commission claimed that the so-called "third-degree" - the practice of torture and harsh interrogation tactics to gain confessions - constituted a national problem ${ }^{6}$. According to the report, urban police forces especially resorted to the torture of prisoners. While the use of police torture methods in cities such as New York, Chicago, and Detroit was directed against prisoners from vari-

police torture in the American South: Silvan Niedermeier, Forced Confessions: Torture, Race and Civil Rights in the American South, 1930-1955 (Erfurt University 2011), [hereafter Niedermeier, Forced Confession].

6 The Report on Lawlessness in Law Enforcement was one of the fourteen reports published by the National Commission on Law Observance and Enforcement, known popularly as the Wickersham Commission, established in May 1929 by President Herbert Hoover to conduct a comprehensive study of crime and law enforcement in the United States. See Zechariab Chafee, Walter H. Pollak, Carl S. Stern, Report on Lawlessness in Law Enforcement (Washington 1931). See also Linards Udris's essay in this volume. 
ous marginalized social and ethnic groups, the practice had a different connotation in the southern states. Police torture was there primarily directed against African Americans and took place within a deeply racist criminal justice system that served to uphold racial segregation and white supremacy?.

The pervasiveness of police torture in the pre-World War II South may have had a complex connection to the decline in lynching. During the 1920s and 1930s, state governments in the region gradually extended their oversight of local criminal justice, in part to clamp down on such extra-judicial violence against African Americans. Lynching did decrease, but pressure for convictions of black defendants remained strong, as did racist assumptions concerning black criminality. This seems to have created an inducement for southern police officers to resort to illegal torture methods in order to force confessions out of African American prisoners and secure their convictions in court. The NAACP rightly perceived police torture as an issue intertwined with lynching. As a consequence, the NAACP's legal department increased its activities in southern forced confession cases in the late 1930 s and early $1940 \mathrm{~s}^{8}$.

Founded in 1909 by black and white civil rights activists in the wake of the Springfield, Illinois, race riot of 1908 , the NAACP quickly became the most influential civil rights organization in the United States. By 1919, NAACP membership had grown to 90,000 . During the period covered by this essay, the NAACP would experience another massive rise in membership, which reached 500,000 by 1946. The organization's popularity stemmed in large measure from its central role in the legal fight against racial segregation, African American disfranchisement, and discrimination in the legal system. The NAACP was also highly visible in lobbying for federal anti-lynching legislation'. Although dedicated to a legal strategy from the start, the NAACP reorganized and strengthened this aspect of its work during the $1930 \mathrm{~s}^{10}$. The vast archival records of the NAACP legal department document hundreds of actions involving issues such as police brutality, jury discrimination, and forced confessions, as well as the denial of fair trials and of the right to counsel11. As Patricia Sullivan has argued, by the second half of the 1930s,

7 On racism and criminal justice in the twentieth-century American South see Jürgen Martschukat, "Little Short of Judicial Murder": Todesstrafe und Afro-Amerikaner, 1930-1972, in: Geschichte und Gesellschaft 30/3 (2004) 490-526.

8 Concerning the decline of lynching in the American South, see Manfred Berg's chapter in this volume and Manfred Berg, Das Ende der Lynchjustiz im amerikanischen Süden, in: Historische Zeitschrift 283 (2006) 583-616; W. Fitzhugh Brundage, Lynching in the New South: Georgia and Virginia, 1880-1930 (Urbana 1993) 239-249.

9 Robert L. Zangrando, The NAACP Crusade against Lynching, 1909-1950 (Philadelphia 1980).

10 Patricia Sullivan, Prelude to Brown: Education and the Struggle for Racial Justice during the NAACP's Formative Years, 1909-1934, in: From the Grassroots to the Supreme Court: Brown v. Board of Education and American Democracy, ed. by Peter F. Lau (Durham 2004) 154-172.

11 John H. Bracey Jr., August Meier, Guide to the Papers of the NAACP, Part 8: Discrimination in the Criminal Justice System, Series B. Legal Department and Central Office Records (Bethesda 1991). 
the NAACP's "legal campaign had eclipsed the national movement for antilynching legislation as a defining element in the NAACP's program" making the "courtroom ... a primary arena in the battle for equal justice"12.

This strategic development was pushed by civil rights attorney Charles Hamilton Houston, whom the NAACP hired in 1935 to serve as the first full-time salaried special counsel13. In 1936, Houston's student and Howard University graduate Thurgood Marshall joined the NAACP legal department as assistant special counsel. Two years later, Marshall succeeded Houston as NAACP special counsel. In 1940, Thurgood Marshall was appointed to head the Legal Defense and Education Fund, the newly established litigation arm of the NAACP. Marshall remained in charge of the NAACP's legal campaign through the landmark 1954 Brown v. Board of Education case and then beyond, until his appointment as a federal judge in 1961. After then serving as U.S. solicitor general, Marshall would become the U.S. Supreme Court's first African American justice in $1967^{14}$.

In an article published in the July 1939 issue of The Crisis, Marshall set forth the strategy of the reorganized NAACP legal department under his leadership. Entitled "Equal Justice Under Law" - the motto engraved above the main entrance to the United States Supreme Court building in Washington, DC - the article referred to the NAACP's achievements in appealing cases of racial discrimination to the Supreme Court. As Marshall pointed out, in the thirty years since its founding, the NAACP had been successful in twelve of thirteen cases that reached the country's high court. According to the civil rights attorney, the court's judgments in cases pursued by the NAACP served as

guide posts in a sustained fight for full citizenship rights for Negroes. They have broadened the scope of protection guaranteed by ... the Constitution in the fields of the right to register and vote, equal justice before the law, Negroes on juries, segregation and equal educational opportunities ${ }^{15}$.

As a result, Marshall argued, the NAACP's legal activities had contributed to securing justice for both black and white Americans:

The campaign to secure equal justice in the courts has brought about several precedents which have been of value to all defendants in criminal cases both Negro and white.... The opinions in these cases define the civil rights of the Negro as a citizen. In addition, they

12 Patricia Sullivan, Lift Every Voice: the NAACP and the Making of the Civil Rights Movement (New York 2009) 249 [hereafter Sullivan, Lift every voice].

13 Houston's appointment was part of a gradual change from a white to black-dominated NAACP staff, as African Americans took over important leadership positions within NAACP departments. Manfred Berg, The Ticket to Freedom: die NAACP und das Wahlrecht der Afro-Amerikaner (Frankfurt a.M. 2000) 174 [hereafter Berg, The Ticket to Freedom].

14 Mark V. Tushnet, Making Civil Rights Law: Thurgood Marshall and the Supreme Court, 1936-1961 (New York 1994) 6-41, 150-176. Also Mark V. Tushnet, Making Constitutional Law: Thurgood Marshall and the Supreme Court, 1961-1991 (New York 1997).

15 Thurgood Marshall, Equal Justice under Law, in: The Crisis (July 1939) 199-201 [hereafter Marshall, Equal Justice]. 
broaden the interpretation of civil rights for all citizens and extend civil liberties for whites as well as Negroes. The activity of lawyers acting for the N.A.A.C.P. has added to the body of civil rights for all Americans ${ }^{16}$.

These statements shed light on the contemporary self-definition of NAACP activists. From their standpoint, the so-called "legal approach" constituted the only promising way to achieve the permanent abolition of racial discrimination and segregation in American society. The NAACP was of course aware of the fact that the legal fight in American courts would not result in an immediate end to racial discrimination. At the same time, they defended their legal approach as the only sure way to secure long-lasting changes in the fields of voting rights, education, segregation, and legal discrimination ${ }^{17}$.

NAACP activities against "forced confessions" were supported by several U.S. Supreme Court decisions during the 1920s and 1930s that were intended to strengthen the constitutional rights of African American defendants in southern courts. As early as 1923, the NAACP had successfully argued in Moore v. Dempsey that the conviction of defendants in a "mob-dominated trial" violated the due process clause of the Fourteenth Amendment to the U.S. Constitution. The Moore decision thereby established a "federal constitutional law of state criminal procedure" that allowed the U.S. Supreme Court to intervene into state criminal cases when they involved a possible violation of due process. Consequently, it allowed NAACP legal activists to appeal southern court cases involving issues of legal discrimination to federal courts ${ }^{18}$. In the two decades following Moore, the Supreme Court handed down several more decisions that broadened the meaning of the Fourteenth Amendment's due process clause. Two of those decisions resulted from the Scottsboro case. This infamous case, which gained national and international attention during the 1930s, involved nine African American defendants who were convicted and sentenced to death by a court in Scottsboro, Alabama, based on the dubious rape allegations by two white women. After their conviction, both the NAACP and the International Labor Defense (ILD), the legal arm of the American Communist party, became involved and indeed struggled at times over the legal representation of the Scottsboro Boys ${ }^{19}$. In $\mathrm{Po}_{0}$ well v. Alabama (1932), the Supreme Court reversed the conviction of the Scottsboro Boys because their right to counsel had been denied. And then in Norris $v$. Alabama (1935), the court overturned the verdict on account of racial discrimi-

16 Ibid.

17 Benjamin Kaplan, The Legal Front: Some Highlights of the Past Year, in: The Crisis (July 1940) 206-207, 210; Marshall, Equal Justice. Also Berg, The Ticket to Freedom 151-182.

18 Michael J. Klarman, From Jim Crow to Civil Rights: the Supreme Court and the Struggle for Racial Equality (Oxford, New York 2004) 117-121, esp. 120 [hereafter Klarman, From Jim Crow to Civil Rights].

19 On the Scottsboro case, Dan T. Carter, Scottsboro; a Tragedy of the American South (Baton Rouge 1969); James A. Miller, Remembering Scottsboro: the Legacy of an Infamous Trial (Princeton, N.J. 2009). 
nation in jury selection. In both cases, the court ruled that the convictions violated the due process clause ${ }^{20}$.

Bolstered by these decisions, the NAACP legal department intensified its efforts concerning the treatment of African Americans in courts throughout the United States but especially within the southern criminal justice system. In doing so, the NAACP paid special attention to forced confession cases. From 1930 to 1955, the NAACP legal department dealt with more than fifty cases in which southern African Americans claimed that they were convicted on the basis of confessions obtained from them by a variety of coercive methods, including physical torture ${ }^{21}$.

Between 1936 and 1945, the Supreme Court accepted eight cases for review that involved the legal issue of forced confession, based upon appeals from southern African American convicts. The court reversed the sentences in all but one of these cases, basing its judgment on the Fourteenth Amendment. In seven of these eight cases, the NAACP legal department was directly involved in the appeal to the high court ${ }^{22}$.

Prior to 1940, the NAACP legal department was highly selective in supporting appeals in southern forced confession cases. As a general strategy, the NAACP only took up cases that could establish legal precedents. According to a memo written by Charles Houston in 1937, the NAACP sought to restrict its legal activities to cases that were of "general interest to Negroes, affecting their civic, economic or political life”. Also, the NAACP's involvement in forced confession cases was hampered by financial restrictions, as bringing a case to the Supreme Court easily involved costs over one thousand dollars, even during the Depression. In view of the difficult financial situation of the NAACP national office during the late 1930s, the legal department could only support appeals in cases which promised a reversal by the Supreme Court and provided fundraising opportunities $^{23}$.

20 Klarman, From Jim Crow to Civil Rights 117-135, 152-158.

21 The number of cases is based upon the entries for "Forced Confessions" in the index of the Guide to the Papers of the NAACP. Part 8: Discrimination in the Criminal Justice System, 1910-1955; Series A: Legal Department and Central Office Records, 1910-1939; Series B: Legal Department and Central Office Records, 1940-1955, Library of Congress (LOC), Manuscript Division, Washington DC. The NAACP papers document 51 forced confession cases from Georgia (9 cases), Mississippi (8), Alabama (7), South Carolina (6), Texas (5), Florida (5), Louisiana (4), Tennessee (3) North Carolina (2), Oklahoma (1), Virginia (1).

22 The cases were: Brown v. Mississippi (1936), Chambers v. Florida (1940), Canty v. Alabama (1940), White v. Texas (1940), Vernon v. Alabama (1941), Lomax v. Texas (1941), Ward v. Texas (1942), Lyons v. Oklahoma (1944). See John F. Blevins, Lyons v. Oklahoma, the NAACP, and coerced confessions under the Hughes, Stone, and Vinson Courts, 1936-1949, in: Virginia Law Review 90 (2004) 387-464, here: 418-419. The only case without NAACP participation was Lomax v. Texas (1941).

${ }_{23}$ Letter from Charles H. Houston to Hubert T. Faulk, Esq., New York City, September 29, 1937, in: NAACP Papers, Young, Roscoe and Henderson, 1937-1938, Group I, Box D-99, LOC. See also Klarman, From Jim Crow to Civil Rights 109-110, 155. 
Moreover, the legal department was reluctant to support appeals in forced confession cases when it remained unclear whether the defendant was innocent of the crime. As Mark V. Tushnet explains, the NAACP was hesitant to work on behalf of guilty defendants as it feared such cases might impair its public image ${ }^{24}$. In fact, NAACP officials often asked local activists to evaluate the innocence or guilt of defendants. However, NAACP records show that the final decision to interfere in criminal trials depended on various factors, ranging from legal considerations and financial restrictions to the individual circumstances of cases. The records contain many examples of NAACP legal activists carefully deciding which cases to support and which not. After all, the refusal to support appeals in southern capital cases could have dramatic consequences, as the NAACP was oftentimes the only institution that could provide legal support for African Americans sentenced to death.

These considerations were evident in the case of Brown, Ellington, and Shields. As the NAACP stated publicly in April 1935, the legal department only became involved in the case after a justice of the Mississippi Supreme Court had challenged the majority's decision upholding the conviction of the three defendants in Brown v. Mississippi. The dissent opened the door for a successful appeal to the U.S. Supreme Court ${ }^{25}$. According to the first report on the case published in The Crisis in April 1935, it was "only because of this strong dissent [by the Mississippi justice] that the N.A.A.C.P. took up this case”26.

\section{"Almost unbelievable in a civilized state": The NAACP and Brown v. Mississippi (1936)}

In March 1936, the Supreme Court announced its unanimous decision in Brown v. Mississippi. It overturned the death sentences of the three African American defendants and ordered a new trial. The justices explicitly criticized the treatment that the three prisoners had received by Mississippi's legal institutions. As the court stated, "It would be difficult to conceive of methods more revolting to the sense of justice than those taken to procure the confessions of these petitioners." 27 The justices made clear that the use of forced confessions in state court procedure

\footnotetext{
24 Tushnet, Making Civil Rights Law 28-29.

25 Contrary to the public statements of the NAACP at the time, a former governor of Mississippi, Earl Brewer, took the initiative in appealing the Brown convictions to the U.S. Supreme Court. As Richard Cortner has shown, the NAACP only provided financial support once the appeal was underway. The Commission on Interracial Cooperation (CIC) and a group of supportive southern whites also gave financial support to the appeal by Brown, Shields, and Ellington. Richard C. Cortner, A "Scottsboro" Case in Mississippi: the Supreme Court and Brown v. Mississippi (Jackson 1986) 64-108.

26 Escapes Noose; Near Death From Torture, in: The Crisis (April 1935) 119.

27 Brown. v. State of Mississippi, 297 U.S. 278 (1936), <http://caselaw.lp.findlaw.com/ scripts/getcase.pl? court=us\&vol=297\&invol=278> (accessed April 2, 2012).
} 
constituted a violation of the Fourteenth Amendment's due process clause ${ }^{28}$. Thus, the decision in Brown v. Mississippi established new constitutional interpretation regarding the admissibility of confessions in state court procedures. As a consequence, it provided the basis for future appeals to the Supreme Court to review state actions in criminal cases involving allegations of forced confessions ${ }^{29}$. Most remarkable was the court's choice of words to denounce the torture practices used by the Mississippi police to force confessions from the three defendants. As the justices pointed out:

The transcript [of this trial] reads more like pages torn from some medieval account than a record made within the confines of a modern civilization which aspires to an enlightened constitutional government ${ }^{30}$.

By calling the incidents in Mississippi a break with modern civilization, the U.S. Supreme Court echoed notions that were also taken up by contemporary newspaper accounts. For instance, the Chicago Daily Tribune commented on the Brown v. Mississippi decision:

The opinion has to do with a murder trial in a backwoods region in Mississippi. It reveals a story of stark terror, torture, and brutality that eclipses even the horror tales of the middle ages. The rope and the lash are exposed as having taken the place of justice in a part of the land ordinarily believed to [be] inhabited by civilized people ${ }^{31}$.

The NAACP also called upon the notion of "civilization" during its public campaign over the Brown case. In a report published a month before the Supreme Court decision, the NAACP summed up the circumstances in Brown with the following words: "The three farm hands were convicted solely upon a 'confession' which was secured from them by beatings and torture almost unbelievable in a civilized state."32

In re-invoking the theme of "civilization" to emphasize the backwardness of southern criminal justice procedures, the NAACP questioned Americans' selfimage as a modern, "civilized" nation. In doing so, the NAACP drew upon rhetorical devices that it had been used extensively throughout its national campaign against lynching.

As historian Gail Bederman points out, the concept of civilization had been used in different contexts in American history to legitimize or challenge claims to power. Since the late nineteenth century, civilization constituted an explicitly racialized (and gendered) conception that blended notions of race differences with Darwinian concepts of human evolution. In social evolutionary discourse, the term "civilization" stood for a stage of human development in which the primitive stage of barbarism and wilderness had been overcome. According to the concept's

28 Ibid.

29 Klarman, From Jim Crow to Civil Rights, 128-130.

30 Brown v. State of Mississippi, 297 U.S. 278 (1936), <http://laws.findlaw.com/us/297/ 278.html> (accessed April 2, 2012).

31 Trio Is Saved From Legal Lynching, in: Chicago Daily Tribune (March 15, 1940) D5.

32 U.S. Supreme Court Hears Their Case, in: The Crisis (February 1936) 42. 
contemporary proponents, the white Anglo-Saxon race had attained the highest stage of civilization, but many other races still remained in stages of backwardness $^{33}$. By inverting this dominant discourse of civilization, civil rights activists such as Ida B. Wells used the concept to dramatize the implications of lynchings of African Americans in the American South. The power of Wells's anti-lynching writings was due in part to her ability to rework the discourse of civilization by reframing southern lynching as barbaric and uncivilized, calling into question America's self-image as a civilized nation ${ }^{34}$. The NAACP used a similar rhetorical strategy to great effect during its national campaign for federal anti-lynching legislation during the 1920s and 1930s. One important example was the way that antilynching activists used lynching photographs - many produced by white spectators and even participants - as visual evidence of southern barbarity and injustice. By defining lynching as a disgrace to American modernity and civilization, the NAACP appealed to white liberals and moderates in both the South and the North to oppose lynching and support the passage of federal anti-lynching legislation ${ }^{35}$.

During its legal campaign against southern police torture, the NAACP employed notions and strategies it had developed during its anti-lynching campaign of the 1920s and 1930s. However, while the anti-lynching campaign had focused on the figure of the barbaric white mob, now the figure of the backward and violence-prone southern system of criminal justice stood at the center of the NAACP campaign against "forced confessions".

Unlike lynching cases, forced confession cases allowed NAACP activists to present themselves as untiring advocates of African American convicts who had become innocent victims of southern criminal justice. In doing so, NAACP activists projected themselves as defenders of American principles of justice. This became evident in another NAACP report on the Brown v. Mississippi case, published in April 1936 shortly after the successful appeal to the U.S. Supreme Court:

Mississippi has been told by the U.S. Supreme Court that the rack and torture chamber may not substitute for the witness chair. Brown, Ellington, and Shields have a new lease of life and the N.A.A.C.P. has another victory to its credit before the high court ${ }^{36}$.

Following Brown v. Mississippi, the NAACP increased its legal activities in forced confession cases. When the NAACP membership rose to an unprecedented height in the early 1940s and the organization's financial situation improved, the fight against forced confessions became one of its main arenas of legal activism. In July 1942, Thurgood Marshall declared in a letter sent to a Florida

33 Gail Bederman, Manliness and Civilization: a Cultural History of Gender and Race in the United States, 1880-1917 (Chicago 1995) 23-31.

34 Ibid. 45-76.

35 Amy Louise Wood, Lynching and Spectacle: Witnessing Racial Violence in America, 1890 1940 (Chapel Hill 2009) 179-221.

36 No Torture, in: The Crisis (April 1936) 113. See also: US Supreme Court Reverses Torture Case, in: The Crisis (April 1936) 118-119. 
lawyer that the NAACP legal department was "vitally interested in the question of convictions obtained as a result of confessions extorted by force and violence" since it had "carried several of these cases to the United States Supreme Court"37. As in the 1936 Brown case, most of these appeals grew out of trials of southern black defendants accused of murder or rape of white persons. Such crimes frequently instigated radical racist sentiments within southern white communities and were the most likely to lead to quick trials based on dubious procedure resulting in death penalties against the accused. As the following section shows, the NAACP used these cases to mobilize public support for its campaign and to promote changes within the American criminal justice system.

\section{Fighting Torture through Litigation: The NAACP's involvement in Chambers v. Florida and Canty v. Alabama}

Most important in this regard was the case of the four African Americans from Florida, Isiah (Izell) Chambers, Jack Williamson, Charles Davis, and Walter Woodward. The case began with the murder of a white planter in Pompano, Florida in May 1933. Following the crime, local law enforcement officers carried out an indiscriminate sweep, arresting 30 to 40 African American suspects. Several of them were detained more than a week without charge in a local jail. They were interrogated day and night, without access to counsel, until four of them confessed to the murder. According to the testimony of the four defendants during the subsequent court trials, the prisoners were subjected to prolonged beating by police officers and white civilians until they confessed to the murder even though scant evidence pointed to their guilt ${ }^{38}$. During the ensuing trial, the four defendants were found guilty by the jury of the Circuit Court of Broward County, Florida, and sentenced to death in the electric chair. Due to the untiring efforts of a local African American lawyer, S.D. McGill, the case was appealed three times to the Florida Supreme Court during the following six years. The Florida Supreme Court twice reversed the conviction against the four defendants. However, after a local court convicted the four defendants for the third time, the Florida Supreme Court upheld the verdict against them. Following the decision, the NAACP legal department appealed the case to the U.S. Supreme Court ${ }^{39}$.

After the Supreme Court heard the case in January 1940, Walter White, the long-time executive secretary of the NAACP, pointed to the symbolic value of appeals to the high court in cases like Chambers:

37 Letter from Thurgood Marshall to E. Norman Lancey. New York City, July 2, 1942, in: Flowers v. Florida. Correspondence, 1942-43, NAACP Papers, Group II Box-123, LOC.

38 Chambers v. State of Florida, 309 U.S. 227 (1940), <http://laws.findlaw.com/us/309/ 227.html> (accessed April 2, 2012).

39 Chambers v. Florida, Correspondence 1940-42, NAACP Papers, Group II, Box B-28, LOC. 
We cannot underestimate the tremendous importance of carrying these cases involving the protection of basic citizenship rights, to the U.S. Supreme Court. I wish we would have fifty such cases brought before the high court every year. I believe it would strengthen the arms of justice in all parts of the county 40 .

On February 12, 1940, the U.S Supreme Court announced its decision in Chambers v. Florida. As in Brown four years earlier, the justices unanimously reversed the verdict against the four defendants and ordered a new trial to be held. Referring to its previous decision, the court ruled that the Florida police and courts had violated the due process clause of the Fourteenth Amendment. In contrast to the Brown decision, however, the justices declared that they were not able to decide whether the defendants had been subjected to physical torture. Instead they argued that the confessions were inadmissible because they had been obtained under "compulsion" 41 .

Chambers v. Florida gained symbolic meaning due to the fact that the court announced the decision on the birthday of Abraham Lincoln, evoking Lincoln's legacy as the "great emancipator". Associate Justice Hugo L. Black departed from the usual Supreme Court procedure by reading the full text of the ruling to the audience in the courtroom. In the opinion, Justice Black pointed to the meaning of due process for criminal procedure and the safeguarding effects of the U.S. Constitution:

Due process of law, preserved for all by our Constitution, commands that no such practice as that disclosed by this record shall send any accused to his death. No higher duty, no more solemn responsibility, rests upon this Court, than that of translating into living law and maintaining this constitutional shield deliberately planned and inscribed for the benefit of every human being subject to our Constitution - of whatever race, creed, or persuasion ${ }^{42}$.

The national press embraced the Supreme Court's decision. Various comments praised the Court's “historic" verdict and stressed its important role as guardian of civil rights and keeper of the constitution ${ }^{43}$. Black and white newspapers pointed out that none other than the former Ku Klux Klan member Hugo L. Black had announced the decision on behalf of the four African American defendants. As the black weekly newspaper Chicago Defender euphorically declared, the decision constituted "another step toward full emancipation for members of the Race in the deep South"44. One day after the decision, the NAACP published a press statement in which Arthur Spingarn, the group's president, emphasized that the Chambers decision had importance for black and white Americans:

40 Walter White is quoted in: Florida's "Scottsboro Case” Goes Before Supreme Court, in: Atlanta Daily World (January 11, 1940) 1.

41 Chambers v. State of Florida, 309 U.S. 227 (1940), (accessed April 2, 2012).

42 Ibid.

43 See: Justice Has No Politics, in: New York Times (February, 131940) 21; Shield of Liberty, in: The Washington Post (February, 13 1940) 12; Outlaw “Torture Confessions". Supreme Court Orders New Trial in Florida 'Scottsboro Case', in: The Pittsburgh Courier (February, 171940) 1.

44 See: High Court Denounces Fla. Justice, in: The Chicago Defender (February, 171940) $1,2$. 
No poor man in America, whether white or colored, can lose hope so long as the United States Supreme Court remains a bulwark protecting the constitutional citizenship rights of the under-privileged and defenseless ${ }^{45}$.

In an editorial published in March 1940, Roy Wilkins, the editor of the Crisis, called the decision a "rebuke to torture". The use of violent interrogation practices, Wilkins emphasized, was not only practiced throughout the United States but was a major feature of the overwhelming legal discrimination against African American defendants in the southern system of criminal justice:

This practice of holding prisoners without warrant, of torturing them and forcing damaging confessions from them is in vogue in many places in our country, but it is part of the routine police procedure in the southern states when Negroes are suspected of crime ${ }^{46}$.

As in its comments on the Brown v. Mississippi case, the NAACP used the successful appeal to the Supreme Court to highlight the precarious situation of African American defendants within southern legal institutions:

The Florida case and the Mississippi case both illustrate the tremendous odds against Negroes arrested in a prejudice-ridden local community where they are at the mercy of local officials and local public opinion. They are terrorized and stripped of all their rights ${ }^{47}$.

In such comments, the NAACP underscored the meaning of its legal fight against forced confessions. The legal campaign was essential to saving African American defendants from lethal punishments resulting from unlawful convictions.

NAACP activists believed that their legal fight was having a reforming effect on criminal justice institutions and police interrogation practices. This became evident in Canty v. Alabama, the NAACP's second successful appeal in a forced confession case in 1940. In March 1938, Dave Canty had been convicted and sentenced to death by a court in Montgomery, Alabama, for the murder of Lillian Ward, a white nurse, and for an attack on her sister, Eunice Ward. Despite the fact that the surviving victim was unable to identify Canty as the perpetrator of the crime, he was indicted and brought to trial in June 1938. During his trial, Canty insisted on his innocence and claimed that daylong beatings by police officers and deputy sheriffs had forced his confession. In court, he presented scars on his body to the jury in order to support his torture claims. Against the objections of Canty and his lawyers, the presiding judge ruled the alleged confession to be admissible as evidence. After a two-day trial, Canty was found guilty by the jury and sentenced to death in the electric chair ${ }^{48}$.

45 See Arthur Spingarn, NAACP Daily Letter, February 13, 1940, in: Chambers v. Florida, Correspondence 1940-42, NAACP Papers, Group II, Box B-28, LOC.

46 Rebuke to Torture, in: The Crisis (March 1940) 81.

47 Ibid.

48 Draft of the Petition for Writ of Certiorari to the Supreme Court of the United States, Dave Canty v. State of Alabama, in: Canty v. Alabama, 1940-1942, NAACP Papers, Group II, Box B-27, LOC. 
The NAACP legal department supported Canty's appeal to the Alabama Supreme Court and - when the state court confirmed the conviction - to the U.S. Supreme Court. Basing their case on the successful appeal in Brown v. Mississippi, the NAACP legal activists sought to use the Canty case to affirm the right under the federal constitution not to be convicted on the grounds of a confession obtained through torture and force. The NAACP lawyers argued that a favorable ruling would deter the use of police torture in the American South. As Thurgood Marshall emphasized in a letter to a local NAACP activist in Alabama: "This is a very important case which not only involves the rights of Dave Canty, but will be of benefit to Negroes in the South in general." 49

Only one month after Chambers, the Supreme Court reversed Dave Canty's conviction without hearing arguments, referring solely to its decision on Chambers v. Florida as legal precedent ${ }^{50}$. In a letter to T.T. Allen, president of the NAACP Montgomery branch, Marshall underscored the importance of these cases. They "reemphasized the precedent that convictions based upon confessions extorted by force and violence amount to a denial of due process of law"51. Marshall also stressed that NAACP involvement in the Canty case had a salutary effect in exposing and stigmatizing police torture against both black and white Americans. As he concluded, "This decision will deter policemen and law-enforcement officials from beating prisoners in order to secure confessions and for this reason will protect not only Negroes but white citizens as well." 52 The NAACP campaign against "forced confessions", therefore, not only intended to establish legal precedents. The association was convinced that its fight would restrain the use of torture within both southern and northern criminal justice institutions and help to modernize the American legal system. At the same time, the NAACP used forced confession cases to document the ongoing relevance of its legal fight against racial discrimination.

\section{"Tortured with Charred Bones!": The NAACP and the Scandal of Torture in the W. D. Lyons Case}

During the early 1940s, the NAACP campaign against forced confessions reached its pinnacle in the case of W.D. Lyons. While the case highlights the NAACP's attempt to fight southern torture practices with both textual and visual means, it also demonstrates the organization's changing rhetoric over the course of U.S. participation in World War II.

49 Letter from Thurgood Marshall to Dr. E.W. Taggart, New York City, June 16, 1938, in: Canty, Dave, 1938-1939, NAACP Papers, Group II, Box L-39, LOC.

50 High Court Saves Another Negro, in: New York Times (March 12, 1940) 22.

51 Letter from Thurgood Marshall to T.T. Allen, New York City, November 4, 1940, in: Canty v. Alabama, 1940-1942, NAACP Papers, Group II, Box B-27, LOC.

52 Ibid. 
The case resulted from a much-publicized murder in Fort Townson, Oklahoma, on New Year's Eve, 1939, when a white couple and their four-year-old son were killed by unknown persons before their house was set on fire. In January 1940, local police officers arrested the twenty-year-old African American W.D. Lyons as a suspect. On March 26, 1940, Roscoe Dunjee, editor of the African American weekly Black Dispatch and president of the NAACP's Oklahoma branch, sent a letter to the NAACP national office in which he pointed out that rumors regarding the torture of W.D. Lyons by the investigating police officers were circulating within the local black community 53 .

When the trial against Lyons was postponed until January 1941, the NAACP legal department deviated from its usual litigation strategy in forced confession cases by entering the case before the appeal stage. In a letter dated January 13, 1941, Dunjee suggested to Thurgood Marshall that the NAACP national office participate from the start by sending Marshall in person to Oklahoma to defend Lyons in the local court. Dunjee suggested that the NAACP would profit from such a step since Marshall's involvement would bring national attention to the NAACP's legal activities: "I believe it would be doing a fine thing to step in right at this point so that the National Office can take the spot-light and therefore revive association activity all over the U.S." 54 Marshall agreed to travel to Hugo, Oklahoma, to defend Lyons in cooperation with Stanley Belden, a local white lawyer who had been retained by local NAACP activists. As Marshall pointed out in his answer to Dunjee, his decision was due to the specific importance of the case and the high probability of a successful reversal: "We all believe that this is a most important case and a sure winner under the recent U.S. Supreme Court decisions. It is a case which we should be in on with all of our resources." 55

During the trial of Lyons in the circuit court at Hugo, Marshall sent letters to the NAACP national office that served as a basis for NAACP news releases ${ }^{56}$. In court, Lyons claimed to have been a victim to brutal mistreatment and prolonged beatings by various officers during his interrogation. NAACP press releases focused on Lyons's account of one scene during the interrogation when police officers had placed a pan containing the charred bones of the crime victims on his lap:

Lyons ... testified that on the night he was arrested he was struck with a board, had his eyes blacked and his head rammed against a brick wall several times, while officers took turns

53 Letter from Roscoe Dunjee to Walter White, Oklahoma City, March 26, 1940, in: Lyons v. Oklahoma, Correspondence, 1940-1941, NAACP Papers, Group II, Box B-39, LOC.

54 Letter from Roscoe Dunjee to Walter White, Oklahoma City, January 13, 1941, in: Lyons v. Oklahoma, Correspondence, 1940-1941, NAACP Papers, Group II, Box B-39, LOC.

55 Letter from Thurgood Marshall to Roscoe Dunjee, New York City, January 18, 1941, in: Lyons v. Oklahoma, Correspondence, 1940-1941, NAACP Papers, Group II, Box B-39, LOC.

56 For example, letter from Thurgood Marshall to Walter White, Oklahoma City, February 2, 1941, in: Lyons v. Oklahoma, Correspondence, 1940-1941, NAACP Papers, Group II, Box B-39, LOC. 
beating him. But, he refused to admit anything, he said. Sometime later, he testified, he was taken up to the County Prosecutor's office, where more than ten officers took turns beating him with black jacks. Then they brought in some of the bones of the burned victims, placing them in his lap. They then continued to beat him until 2.30 in the morning, he said, when he finally "confessed".

In fact, during trial, the investigating police officers admitted that they had placed the pan in Lyons's lap. However, they denied that Lyons had been subjected to physical violence during the interrogation. When Lyons's confessions were introduced as evidence by the state's attorney, the local judge ruled out the first confession secured immediately after the incident with the pan. However, despite the objection of Marshall and Belden, the judge declared valid a second confession of Lyons, obtained two days after the incident ${ }^{57}$. On January 30, 1941, after a four-day trial, Lyons was found guilty by the all-white jury and sentenced to life imprisonment. The very fact that the jury members recommended life imprisonment - instead of a death sentence, the usual punishment of African Americans found guilty of murder in southern courts - indicated that the jurors were uncertain about Lyons's guilt ${ }^{58}$.

In a letter to NAACP executive secretary Walter White shortly after the trial, Marshall suggested using the case to initiate a nationwide money drive that would allow the NAACP to fill up its exhausted financial resources. As Marshall pointed out, the specific circumstances of the Lyons case provided a promising starting point for this step:

This case has enough angles to raise a real defence fund over the country if handled properly. ... We could use another good defence fund and this case has more appeal than any up to this time. The beating plus the bones of dead people will raise money.... We have been needing a good criminal case and we have it. Let's raise some real money ${ }^{59}$.

In March 1941, the NAACP published a full-page announcement of the Lyons case in the Crisis. The article entitled "Tortured with Charred Bones" featured a photograph of Lyons in a prison suit. As the shadow and the scenery in the back indicated, Lyons was standing outside in sunlight while the photograph was made. His eyes were fixed on a point to the right of the camera; he seemed to avert his view away from the photographer. Lyons's hands were held together by handcuffs (see figure 2$)^{60}$.

The article accompanying the photograph started with the following lines:

This man, 20 years of age, was convicted on January 31, 1941, of murdering a white man, his wife and 4-year-old child, on the night of December 31, 1939, near Fort Townson, Oklahoma. Lyons is supposed to have "confessed" to the crime. The "confession" was secured by

57 Negro's Statement Ruled Out at Hugo, in: The Daily Oklahoman (February 1, 1941) 1.

58 Klarman, From Jim Crow to Civil Rights 171, 229-230.

59 Letter from Thurgood Marshall to Walter White, Oklahoma City, February 2, 1941, in: Lyons v. Oklahoma, Correspondence, 1940-1941, NAACP Papers, Group II, Box B-39, LOC.

60 Tortured with Charred Bones, in: The Crisis (March 1941) 85. 
Figure 2: Photograph of W. D. Lyons, accompanying the article entitled "Tortured with Charred Bones" in The Crisis, March 1941.

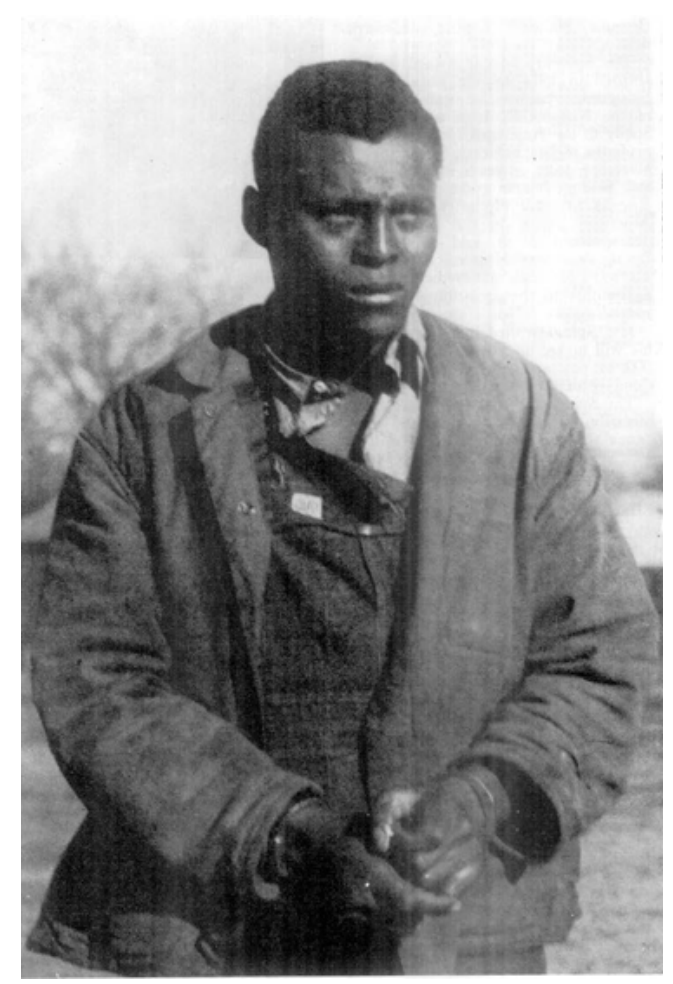

placing the charred bones of the dead people in his lap, and by rubbing Lyons's arm with the teeth and jaw-bone of the dead woman! 61

By pointing to the unusual circumstances of the case, the editors sought to highlight the inhumane treatment of W.D. Lyons by southern police officers. The photograph underscored this intention by showing Lyons in person, thus establishing a referential relation between the article's headline "Tortured with Charred Bones" and the actual victim of mistreatment. In the announcement, the Crisis editors employed a visual strategy that had been used before during the NAACP's anti-lynching campaign. As Amy Wood has shown, from the early 1910s on, activists fought southern lynching by reframing lynching photographs that had been made by white southerners to record, document, and spread lynching's message of white superiority and black depravity. By reproducing and re-contextualizing these photographs in magazines, leaflets, and public exhibitions, antilynching activists changed the meaning of those photographs, using them to serve

61 Ibid. (italics original). 
as "a graphic testimony of the terrible wrongs that white mobs were inflicting on black Americans" 62 .

In the Lyons case, the NAACP again adopted this strategy. Lacking their own photograph, the NAACP reproduced a picture made by Oklahoma's law enforcement officials during their investigation. Instead of presenting Lyons as a murder suspect, the NAACP used the picture to depict him as a victim of southern legal injustice. Similar to lynching photographs used during the NAACP anti-lynching campaign, the re-contextualization of Lyons's photograph led to a reinterpretation of the picture's message. At the same time, the picture and its use in the Crisis differed in one important aspect from lynching photographs. Unlike lynching photographs, which documented the sweeping powerlessness of African Americans within the southern racial order, the picture of Lyons enabled readers to positively identify with a surviving victim of southern racial violence and discrimination ${ }^{63}$.

Pointing to the unusual circumstances of the case, the article also asked readers to contribute to the NAACP's legal campaign. As the editors argued, a donation to the case would not only help Lyons but also strengthen American democracy:

While we are talking about the beauties of democracy and the necessity of strengthening our American system by giving justice to all, why not make a contribution to this Lyons case a testimony to our faith in democracy and our determination that it shall work? Why not a defense fund for all the black men the N.A.A.C.P. is called upon to defend? Why not $\$ 10,00064$ ?

As the passage shows, the Lyons case prompted the NAACP to place its fight against racial discrimination within the national debate about the need to defend America's democracy during World War II. While during the late 1930s, the NAACP had used the notion of civilization to attack southern torture, by the early 1940s, it added the call for democracy to its public campaign. This strategy also became clear in another statement by NAACP activists issued in June 1943, shortly after the Oklahoma Supreme Court sustained the verdict against Lyons. NAACP officials stated:

The methods used in obtaining the confession in the case [of W.D. Lyons] have no parallel in American jurisprudence. Such treatment of an American citizen by officers of the State of Oklahoma strikes at the very foundation of the principles of democracy, now threatened from without as well as from within 65 .

Here again, the NAACP linked America's fight for democracy in World War II to the ongoing use of torture within the American judicial system. In this way, the comment reflected the growing willingness of black American citizens to protest against their ongoing discrimination at home while black men and women de-

62 Wood, Lynching and Spectacle 179-221, quotation 185.

63 James Allen (ed.), Without Sanctuary: Lynching Photography in America (Santa Fe 2000).

64 Tortured with Charred Bones, in: The Crisis (March 1941) 85 (italics in original).

65 Oklahoma Murder Case is Upheld, Appeal to U.S. Supreme Court, in: New York Amsterdam News (June, 261943) 5. 
fended democracy abroad66. By insisting upon Lyons's status as an "American citizen" and denouncing his treatment as an attack on the "principles of democracy", the NAACP questioned the moral stance of the American nation fighting for freedom and democracy abroad while tolerating torture on the home front. As Mary L. Dudziak has shown, civil rights activists pursued this strategy well into the second half of the twentieth century, using cases of racial violence and discrimination within the United States to question America's self-image as a defender of freedom and democracy during the Cold War era ${ }^{67}$.

In the case of W.D. Lyons, however, the NAACP's rhetorical strategy proved to be fruitless: On June 5, 1944, the U.S. Supreme Court sustained his sentence of life imprisonment. Much to the surprise of the NAACP legal team, the majority of the Supreme Court justices followed the reasoning of the lower court, arguing that the second confession of W.D. Lyons was made "voluntarily". On October, 9, 1944 , the Supreme Court denied the NAACP's plea for a rehearing of the case ${ }^{68}$.

\section{Conclusion}

It is difficult to determine the actual effects of the NAACP's legal fight against forced confession that started in the mid-1930s. NAACP archival records document dozens of forced confession cases that reached the legal department between the 1930s and the 1950s, despite the Supreme Court's decisions in Brown and Chambers. Possibly the only immediate consequence of the court's decisions was that southern law enforcement officers started to be more reluctant to admit to police torture practices in open court, which placed the burden of proving torture claims on the shoulders of African Americans defendants and their attorneys. As a consequence, southern African American defendants were still likely to be convicted on forced confessions despite the Supreme Court's rulings and the NAACP's involvement.

Moreover, it is highly doubtful that NAACP legal activism and U.S. Supreme Court decisions had a reforming impact on the everyday use of police brutality against African American prisoners in the South. Even liberal white southerners were reluctant to criticize southern police officers for mistreating African American citizens, as police forces were seen as the most important institution for upholding the southern system of segregation. As a result, southern police officers

66 Berg, The Ticket to Freedom 186-196; Sullivan, Lift every voice 237-252.

67 Mary L. Dudziak, Cold War Civil Rights: Race and the Image of American Democracy (Princeton 2000).

68 U.S. Supreme Court, Lyons v. Oklahoma, 322 U.S. 596 (1944), <http://laws. findlaw.com/ us/322/596.html>, last viewed October 5, 2010; Letter from Charles Elmore Cropley, Clerk of Supreme Court of the United States, to Thurgood Marshall, Washington D.C., October 9, 1944, in: Lyons v. Oklahoma, Correspondence, 1940-1941, NAACP Papers, Group II, Box B-39, LOC. 
usually did not fear legal retribution for brutalizing African American suspects during criminal investigations. Only when the U.S. Department of Justice started federal civil rights investigations against southern police officers accused of police brutality against African American prisoners did this situation change gradually ${ }^{69}$.

On the other hand, one can argue that the NAACP legal campaign against torture was successful since it had long-term legal and moral implications. The NAACP's fight against forced confessions established important legal precedents that rescued southern African Americans from unlawful convictions. These efforts helped to build a legal barrier against illegal police interrogation practices, paving the way to the Supreme Court decision in Miranda v. Arizona in $1966^{70}$.

In using southern torture incidents to highlight contradictions within modern Americans' self-perception, NAACP legal activists portrayed themselves as true modernizers as they both combated barbarous police practices and expanded the constitutional rights of black and white American citizens. In this way, they aligned themselves with ideals of justice and progress and challenged notions of black inferiority and otherness. The NAACP fight against southern torture gave voice to countless African American victims of police brutality in the American South during the late 1930s and early 1940s and stimulated various forms of protests and resistance inside and outside of southern courtrooms.

At the same time, NAACP activities against forced confessions helped to set up a referential relation between southern racial violence and broader American values. When the NAACP legal department initiated its legal campaign against forced confession, it pointed to the inhumanity of southern torture practices and placed them in a larger framework of America's self-image as a "modern", "civilized", and "democratic" society. By employing these rhetorical strategies, the NAACP fight against forced confessions reinforced the perception that southern racial violence constituted a national problem that awaited a solution.

The NAACP campaign was, therefore, another example of how civil rights activists pushed the fight against racial discrimination by pointing to the inconsistencies between American self-perception as a modern society and the continuities of racial violence in the American South and beyond. After World War II, southern African American citizens took up these notions by reinforcing their call for fundamental changes in southern race relations.

69 On the issue of federal Civil Rights investigations in southern police torture cases see Niedermeier, Forced Confession. Also Michael J. Klarman, Is the Supreme Court Sometimes Irrelevant? Race and the Southern Criminal Justice System in the 1940s, in: Journal of American History 89/1 (2002) 119-153, here 127-128.

70 On the impact of Brown v. Mississippi (1936) and Chambers v. Florida (1940) upon the Supreme Court's decision in Miranda v. Arizona (1966), Brown, Coerced Confessions. 


\section{Summary}

Der Beitrag untersucht den Rechtskampf der afroamerikanischen Bürgerrechtsorganisation National Association for the Advancement of Colored People gegen die Praxis der Polizeifolter an afroamerikanischen Angeklagten im US-amerikanischen Süden zwischen 1935 und 1945. Dabei werden zum einen die institutionellen und rechtlichen Hintergründe der NAACP-Kampagne in den Fokus gerückt und nach ihrer Auswirkung auf das südstaatliche Justizsystem gefragt. Zum anderen untersucht der Aufsatz die diskursive Rahmung der südstaatlichen Polizeifolter in den öffentlichen Stellungnahmen der NAACP. Wie gezeigt wird, stand die Kampagne der NAACP in einem engen Bezug zu Diskursen über Modernität und Fortschrittlichkeit. So griff die NAACP wiederholt auf Begriffe wie Moderne, Zivilisation und Demokratie zurück, um die Inhumanität und Rückständigkeit der Strafjustiz des Südens herauszustellen.

In Anknüpfung an ihre Anti-Lynching-Kampagne argumentierte die NAACP, dass die südstaatliche Praxis der Polizeifolter das Selbstbild der USA als moderne und zivilisierte Nation in Frage stelle. Zugleich präsentierten sich die Rechtsanwälte der NAACP als Modernisierer des US-amerikanischen Justizsystems und forderten damit rassistisch codierte, schwarze Rollenvorstellungen heraus. Einer der maßgeblichen Effekte der NAACP-Kampagne bestand darin, dass es die weithin tolerierte Gewalt der Polizeifolter im Süden der USA öffentlich sichtbar machte. Damit verstärkte sie die Wahrnehmung, dass der Rassismus im US-amerikanischen Süden ein nationales Problem darstelle, das einer nachhaltigen Lösung bedürfe. 
